\title{
Simple Laboratory and Clinical Parameters as Predictor for Electrocardiographic Abnormalities Among Hospitalized Patients with Chronic Kidney Disease: A Cross-Sectional Study
}

\author{
Rerdin Julario ${ }^{1}$, Ricardo Adrian Nugraha ${ }^{1}$, Bagus Putra Dharma Khrisna ${ }^{1}$, Tony Santoso Putra ${ }^{1}$, Eka \\ Prasetya Budi Mulia ${ }^{1}$, Ryan Enast Intan ${ }^{2}$, Firas Farisi Alkaff ${ }^{3}$ \\ ${ }^{1}$ Department of Cardiology and Vascular Medicine, Faculty of Medicine, Universitas Airlangga - Dr. \\ Soetomo General Academic Hospital, Surabaya, Indonesia \\ ${ }^{2}$ Department of Medicine, Faculty of Medicine, Universitas Airlangga, Surabaya, Indonesia \\ ${ }^{3}$ Department of Pharmacology, Faculty of Medicine, Universitas Airlangga, Surabaya, Indonesia \\ Corresponding email: firasfarisialkaff@fk.unair.ac.id
}

\begin{abstract}
:
Background: In developing countries, even electrocardiography (ECG) hasn't been used widely in most health-care centers. The ability of physicians to refer to chronic kidney disease (CKD) patients for ECG, often collide with several barriers and costs. Therefore, we need to formulate the simplest and most efficient model to predict when CKD patients need to be referred due to potential ECG abnormalities.
\end{abstract}

Objective: The aim of this study was to develop several clinical and laboratory parameters as a predictor of any ECG abnormalities.

Materials and Methods: A retrospective cross-sectional study design held at Dr. Soetomo General Academic Hospital, Surabaya, Indonesia. Subjects were hospitalized patients with CKD between 1 January to 31 December 2019. 198 CKD patients (101 males) were enrolled for the study. All patients had demographic information, detailed clinical profile, resting 12-lead ECG recording, complete blood count, serum electrolyte and renal function test profile during admission and results were interpreted blindly by two cardiologists. Statistical analysis was done by SPSS 17.0.

Results: A total of 198 patients were included in this study. Mean ages were $52.2 \pm 11.8$ years old and fifty-one percent were males. Eighty-eight percent of patients from 198 patients had ECG abnormality. AUC of hemoglobin level to discriminate poor $\mathrm{R}$ wave progression, pathological $\mathrm{Q}$ wave, non-spesific ST$T$ changes, and frontal axis deviation were $0.532,0.641,0.556$ and 0.693 , respectively. In multivariate logistic regression analysis, only higher systolic blood pressure was determined as an independent predictor of abnormal ECG finding in CKD patients, as systolic blood pressure increase by one unit, the odds of having abnormal ECG is increased 1.02 times (95\% $\mathrm{Cl}: 1.00-1.02, p=0.042)$.

Conclusion: The ECG abnormalities can be found in hospitalized CKD patients. Fragmented QRS and long QTc were the highest prevalent ECG abnormalities in our study. Serum creatinine and hemoglobin could predict peaked T wave and prolonged QTc among hospitalized CKD patients. Systolic blood pressure could predict prolonged QTc and fragmented QRS in CKD patients.

Keywords: fragmented QRS, peaked T wave, poor $R$ wave progression, prolonged QTC, chronic kidney disease 


\section{INTRODUCTION}

Chronic kidney disease (CKD) is associated with various kinds of complications that lead to poor health outcomes. The risk of cardiovascular disease (CVD) has increased in patients with CKD even before reaching End-Stage Renal Disease (ESRD). The mortality rate in dialysis patients due to cardiovascular complications is high. The prognosis in developing countries is poor due to inadequate diagnostic and late presentation[1].

KDIGO 2012 recommends active intervention by paying attention to the conditions of CVD and related comorbidities to reduce hospitalization and mortality for people with CKD[2]. Based on the guideline principles, CKD patients need to be closely monitored for early signs and symptoms of CVD. Even annual ECG monitorings are mandatory to detect any sign of CVD at an early stage. Unfortunately, many clinicians, particularly in developing countries, face a big problem to adopt these recommendations [3]. Such as electrocardiography (ECG) hasn't been used widely in most health-care centers. Therefore, patients need to be referred to bigger health-care centers or hospitals. On the other hand, the ability of physicians to refer chronic kidney disease (CKD) patients for ECG examination or comprehensive specialist treatment, often collide with the geographical barrier, accessibility, patients' belief, policy, cost, and insurance[3]. Patients with CKD in developing countries usually seek medical advice after falling at an advanced stage due to a lack of awareness, education, financial constraints, and medical facilities[4, 5].

Due to several barriers, the decision of whether to refer CKD patients to comprehensive specialist treatment or even for ECG measurement is challenging and confusing for many clinicians. In addition, only a few studies provide information on the frequency of ECG changes in the local CKD population which can make the physician less aware of the complications of CVD in CKD[6]. The frequency and predictor of ECG abnormalities in CKD patients in Indonesia may also be different from the literature that has been reported[7]. Therefore, we need to formulate the simplest and most efficient model from the clinical and laboratory parameters to predict the time when CKD patients need to be referred due to potential ECG abnormalities. Since there is a lack of Indonesian-based research about predictor model for ECG abnormalities on CKD patients, we develop our model from several clinical and simple laboratory parameters to predict any ECG abnormalities in CKD patients treated in a referral hospital in Indonesia. 
medRxiv preprint doi: https://doi.org/10.1101/2021.01.15.21249916; this version posted January 20, 2021. The copyright holder for this preprint (which was not certified by peer review) is the author/funder, who has granted medRxiv a license to display the preprint in perpetuity. All rights reserved. No reuse allowed without permission.

\section{MATERIALS AND METHODS}

\section{Ethical clearance}

Institutional ethics and research committee approved the study. Dr. Soetomo General Academic Hospital conferred ethical clearance for this study. Compliance with ethical standards, this research proposal was approved by the ethical committees of Dr. Soetomo General Academic Hospital in collaboration with Universitas Airlangga College of Medicine Research Ethics Council (Ref: 1811/KEPK/II/2020) under the name of Rerdin Julario as the Principal Investigator.

\section{Study design and study setting}

This study was an analytic observational study using a retrospective cross-sectional study design. This study held at Dr. Soetomo General Academic Hospital, Surabaya, Indonesia. Dr. Soetomo General Academic Hospital is the biggest hospital in East Java and also the referral hospitals for East Indonesia region with an academic affiliation with Faculty of Medicine, Universitas Airlangga. All patients between the ages of 15-90 years with known or newly diagnosed CKD admitted at the internal medicine ward were included. The study was conducted over 12 months period from 1 January to 31 December 2019.

\section{Population and sample}

All patients in different stages of CKD were included in this study. Patients with unstable hemodynamic, history of cardiac arrest, previously consumed antiarrhythmic drugs and lack of complete medical record data were excluded. This study used consecutive sampling.

\section{Outcomes and variables}

Potential cases of CKD were identified by an eGFR $60 \mathrm{ml} / \mathrm{min}$ per $1.73 \mathrm{~m}^{2}$. To predict the risk of CV in previous epidemiological studies, we can use an eGFR threshold of $60 \mathrm{ml} /$ min per $1.73 \mathrm{~m}^{2}$ [2]. Estimated GFR (eGFR) was calculated using the CKD-EPI equation [8]. Medical records, Patient's history, and laboratory information were reviewed to gain data on patient's age, gender, history of hyperglycemia, hypertension, resting heart rate, systolic and diastolic blood pressure, serum creatinine, blood ureum nitrogen, eGFR, electrolytes, and complete blood count. The patient was classified to have ECG abnormalities if one of the ECG parameters didn't fulfill the reference range.

\section{Data collection}

All patients had resting 12-lead ECG examination. All ECGs were reviewed with the following parameters: heart rhythm, heart rate, frontal axis, P wave, PR interval, QRS duration, pathological Q wave, fragmented QRS morphology, QTc interval, ST-segment deviation, and T wave morphology; by two independent consultant physicians. The aforementioned parameters were studied and measured manually and compared with published normal values. The normal limit and definition used for this study were shown in table 1 and table 2 . The abnormal findings were defined if were away from minimal or maximal limits or normal morphology. Precordial lead subjective assessments of the peaking of the $T$ wave were also noted. Subsequent ECGs if done were not analyzed for study purposes. Descriptive results were presented in frequency and percentage. Analytic results were presented in ROC curve.

\section{Statistical analysis}

For bivariate analysis, $\chi^{2}$-test was used for analyzing categorical data, and independent t-test or MannWhitney $U$ test was used for continuous data as appropriate. For univariate and multivariate analysis, the logistic regression model was performed with backward selection. Model calibration was tested with 
medRxiv preprint doi: https://doi.org/10.1101/2021.01.15.21249916; this version posted January 20, 2021. The copyright holder for this preprint (which was not certified by peer review) is the author/funder, who has granted medRxiv a license to display the preprint in perpetuity.

All rights reserved. No reuse allowed without permission.

the Hosmer-Lemeshow test. The accuracy of the test was evaluated based on ROC curve analysis. The results on the level of $p<0.05$ were assumed to be statistically significant. All statistical analyses were performed using SPSS 26.0 (IBM SPSS Statistics for Windows, IBM Corporation, Armonk, NY). 
medRxiv preprint doi: https://doi.org/10.1101/2021.01.15.21249916; this version posted January 20, 2021. The copyright holder for this preprint (which was not certified by peer review) is the author/funder, who has granted medRxiv a license to display the preprint in perpetuity.

All rights reserved. No reuse allowed without permission.

\section{RESULTS}

\section{Baseline characteristic of the study}

A total of 198 patients were included in this study. Characteristics of the study population are summarized in (Table 3 ). The mean age of all patients was $52.2 \pm 11.8$ years old. A total of 101 patients (51\%) were males. Mean serum creatinine was $10.5 \pm 8.0 \mathrm{mg} / \mathrm{dL}$ and mean eGFR was $10.6 \pm 14.4$ $\mathrm{mL} / \mathrm{min} / 1.73 \mathrm{~m}^{2}$. Most patients were in stage 5 of CKD, which was 164 patients (82.8\%). 56.1\% (111 patients from 198 patient) patients had hypertension, $37.9 \%$ had diabetes mellitus, and $24.7 \%$ had a known history of CVD. The mean systolic and diastolic blood pressure was $142.1 \pm 28.2 \mathrm{mmHg}$ and $83.7 \pm 16.3 \mathrm{mmHg}$ respectively. $143(72.2 \%)$ had anemia with mean hemoglobin level was $8.1 \pm 2.3 \mathrm{~g} / \mathrm{dL}$. As the result, the ECG abnormality can be found in 176 or almost $88.9 \%$. Another abundant comorbidity was metabolic acidosis (31.8\%). Most patients had high (45.5\%) or normal (44.9\%) serum potassium, and only $9.1 \%$ of patients had low serum potassium, with mean serum potassium was $4.8 \pm 1.06 \mathrm{mEq} / \mathrm{L}$.

Abnormal ECG findings

Various ECG changes are observed in Table 4

Cut-off value for serum creatinine and other biomarkers to discriminate long QTc interval

The cut-off value of serum creatinine to discriminate long QTc can be seen in ROC Curve in figure 1. For bivariate analysis, serum creatinine is positively discriminate long QTc based on ROC curve (Figure 1) with area under curve (AUC) $0.544(P<0.001)$ with the best cut off serum creatinine level at 7.58 (sensitivity $62 \%$ and specificity $50 \%$ ) (Table 5 ).

Cut-off value for serum creatinine and other biomarkers to discriminate fragmented QRS

The cut-off value of serum creatinine to discriminate fragmented QRS can be seen in ROC Curve (Figure 2). For bivariate analysis, serum creatinine is a negative predictor for fragmented QRS based on ROC curve with area under curve (AUC) 0.496 (Table 6).

Cut-off value for serum creatinine and other biomarkers to discriminate left ventricle hypertrophy The cut-off value of serum creatinine to discriminate left ventricle hypertrophy (LVH) can be seen in ROC Curve (Figure 3). For bivariate analysis, serum creatinine is positively discriminate LVH based on ROC curve with area under curve (AUC) $0.635(P<0.001)$ with the best cut off serum creatinine level at 7.045 (sensitivity $81 \%$ and specificity $46 \%$ ) (Table 7 ).

Cut-off value for serum creatinine and other biomarkers to discriminate peaked $T$ wave

The cut-off value of serum creatinine to discriminate peaked T wave can be seen in ROC Curve (Figure 4). For bivariate analysis, serum creatinine is positively discriminate peaked $T$ wave based on ROC curve with area under curve $(A \cup C) 0.708(P<0.001)$ with the best cut off serum creatinine level at 9.03 (sensitivity $77 \%$ and specificity $61 \%$ ) (Table 8 ).

Cut-off value for hemoglobin concentration and other biomarkers to discriminate poor precordial $R$ wave progression

For bivariate analysis, serum creatinine was a negative predictor for poor precordial $\mathrm{R}$ wave progression based on ROC curve (Figure 5) with AUC 0.464 (Table 9).

Cut-off value for hemoglobin concentration and other biomarkers to discriminate pathological $Q$ wave For bivariate analysis, serum creatinine was a negative predictor for pathological $Q$ wave based on ROC curve (Figure 6) with AUC 0.397 (Table 10). 
medRxiv preprint doi: https://doi.org/10.1101/2021.01.15.21249916; this version posted January 20, 2021. The copyright holder for this preprint (which was not certified by peer review) is the author/funder, who has granted medRxiv a license to display the preprint in perpetuity.

All rights reserved. No reuse allowed without permission.

Cut-off value for hemoglobin concentration and other biomarkers to discriminate non-specific ST-T changes

For bivariate analysis, serum creatinine was a negative predictor for non-specific ST-T changes based on ROC curve (Figure 7) with AUC 0.406 (Table 11).

Cut-off value for hemoglobin concentration and other biomarkers to discriminate frontal axis deviation For bivariate analysis, serum creatinine was a negative predictor for frontal axis deviation based on ROC curve (Figure 8) with AUC 0.462 (Table 12).

Univariate and multivariate analysis for ECG abnormalities

A multivariate analysis was used to see the most important factor for ECG abnormalities in CKD patients. Prolong QTc interval and fragmented QRS was used as the marker of ECG abnormality, because of their importance as predictors of long-term mortality and also as the most common abnormal ECG findings in our population. There were 110 (55.55\%) patients who have QTc interval prolongation or fragmented QRS, or both. The variables whose $P$-value $<0.25$ in univariate analysis from baseline characteristics and laboratory findings were specified as potential risk markers and included in the full model (Table 13). In the univariate analysis, blood urea nitrogen (BUN), systolic and diastolic blood pressure, and potassium level were identified as potential risk predictors. However, in multivariate logistic regression analysis, only higher systolic blood pressure was determined as an independent predictor of abnormal ECG finding in CKD patients, as systolic blood pressure increase by one unit, the odds of having abnormal ECG are increased 1.02 times $(95 \% \mathrm{Cl}: 1.00-1.02, p=0.042)$. Further analysis was done using ROC curve to determine systolic blood pressure cut off, and the best optimal cut off was $140 \mathrm{mmHg}$ (sensitivity $60 \%$, specificity 59\%, AUC 0.57). 
medRxiv preprint doi: https://doi.org/10.1101/2021.01.15.21249916; this version posted January 20, 2021. The copyright holder for this preprint (which was not certified by peer review) is the author/funder, who has granted medRxiv a license to display the preprint in perpetuity.

All rights reserved. No reuse allowed without permission.

\section{DISCUSSION}

The long-term CKD influences the pathogenesis of cardiorenal syndromes, cardiovascular diseases, cardiovascular risk factors, and substantial cardiovascular mortality, there is a need to screen Indonesian CKD patients who are at risk of getting earlier complications [9]. Renal dysfunction is an independent and significant contributor to worse cardiovascular outcomes[10]. Serum creatinine levels are frequently used as a screening test to assess renal dysfunction[11]. This study also explored the potential role of serum creatinine as a parameter for hospitalized CKD patients for getting cardiovascular diseases and/or cardiac arrhythmias. Even though serum creatinine is conventional and old-fashioned diagnostic tools, however, it is cost-effective, rapidly, and highly applicable to larger cohorts of CKD patients compared with the more expensive, more sophisticated, more laborious, timeconsuming serum human neutrophil gelatinase-associated interleukin-18 (IL-18), cystatin-C (cys-C), lipocalin (NGAL), kidney injury molecule-1 (KIM-1), fibroblast growth factor-23 (FGF-23), carboxy-terminal fragment of insulin-like growth factor binding protein-4 (CT-IGFBP-4) and liver-type fatty acid-binding proteins (L-FABP) required for the identification of early cardiovascular diseases in acute kidney injury patients[12, 13].

In our model, serum creatinine had the highest AUC value to predict left ventricular hypertrophy (LVH). Our results might be supported by Leoncini et al (2004), which concluded that creatinine clearance proved to be a very sensitive marker of clinical and subclinical cardiovascular damage[14]. LVH is a well-established sign of cardiovascular damage and also an independent predictor of future cardiovascular morbidity in CKD patients[14]. Although conventional ECG has been thought to be a less specific method than echocardiography for detecting LVH, however, its specificity is even greater than echocardiography. Thus, the more severe the LVH is on echocardiography, the more likely it would be diagnosed on ECG[15]. Serum creatinine also had higher AUC to predict peaked T wave and long QTC interval, compared to serum potassium. This fact might be interesting because serum potassium had long been used as a strong predictor for peaked T wave. Activation of the potassium channels can stimulate speeding up membrane repolarisation, cause inactivates sodium channels can make membrane become depolarized[16]. in hyperkalemia, typical ECG findings progress from shortened QTc interval, and tall, peaked T waves [17]. Hyperkalemia stimulates activation of potassium channel and inactivation of sodium channels which causes shortening QTc interval, sluggish cardiac conduction, widening of the QRS complex and smaller P waves [16]. Moreover, in our model, serum creatinine showed a stronger predictor for peaked $T$ wave compared to serum potassium in hospitalized CKD patients. This fact might be explained by an absence of hydro-electrolytic alterations in many CKD patients. However, calcium also plays a role in T wave amplitude. [18]. Another literature had published that hyperkalemia doesn't always include changes in the abnormality ECG, especially in the amplitude of $T$ wave, as a progressive elevation of serum potassium doesn't always make the auricular muscle unresponsive[19, 20].

The phenomenon of higher serum creatinine correlate with long QTc interval could be explained by numerous factors influencing the QT interval: 1) Patients with CKD often take many medications that can cause QT prolongation; 2) Secondary hyperparathyroidism, a common complication of CKD, could lead to hypocalcemia and hypomagnesemia; 3) Renal anemia, macrocytosis and anisocytosis are also related to prolonged QT intervals due to subsequent hypoxia, autonomic dysfunction and decreased myocardial oxygen supply; 4) Impairment of delayed rectifier potassium channels; 5) Hypertension can significantly reduce potassium current densities ( $I_{\text {peak, }}, I_{t o}, I_{k u r}, I_{s s}$, and $I_{k 1}$ ) and increase the L-type calcium channel; and 6) Reactive oxygen species and uremic toxin leading to inflammatory condition and oxidative stress itself may also predispose to cardiac electrical remodeling[21, 22]. Therefore, the prolongation of the QTc interval is common in hospitalized patients with CKD. 
medRxiv preprint doi: https://doi.org/10.1101/2021.01.15.21249916; this version posted January 20, 2021. The copyright holder for this preprint (which was not certified by peer review) is the author/funder, who has granted medRxiv a license to display the preprint in perpetuity.

All rights reserved. No reuse allowed without permission.

Hemoglobin concentration often reflects duration and chronicity in individuals with CKD, although its level fluctuates frequently [23]. Recent studies suggest that a lower hemoglobin concentration is related with subsequent cardiovascular mortality and increased risk of coronary artery disease in hospitalized patients with CKD, such as CONFIRM-HF Trial [24], IRON OUT HF Trial [25], TIME Trial [26], GUSTO IIb Trial [27], PURSUIT Trial [28], PARAGON B Trial [29], ANCHOR Study [30], and ARIC Study [31]. On the other hand, our study explained that higher hemoglobin concentration showed a strong predictor for pathological Q wave, non-specific ST-T changes, and frontal axis deviation. We believed that the effect of higher hemoglobin concentrations on ECG abnormalities varies across various subtypes of cardiovascular diseases. If the state of anemia continues chronically, the hemodynamic changes found in anemia can contribute to left ventricular hypertrophy and progressive arterial walls [32]. In addition, the hemodynamic changes found in the higher hemoglobin concentration might be primarily determined by the viscosity of blood. Greater hematocrit concentrations would thus significantly slowing its flow rate throughout the body, thicken the blood, raising the peripheral vascular resistance, and reducing coronary blood flow and perfusion to various tissues including the cardiomyocyte. The linked, mechanisms, pathogenesis and pathophysiology of coronary artery disease (CAD) in CKD are complex. Many shreds of evidence clearly stated a significant association between lower or higher hemoglobin concentration and the development of CAD or poor outcomes in patients with known CAD, Therefore, ECG abnormalities such as pathological $Q$ wave (reflects previous myocardial infarction), non-specific ST/T changes (reflects intrinsic myocardial diseases i.e. ischemia) and frontal axis deviation (sign of hypertrophy or reduced muscle mass or conduction abnormalities) are just suggesting the existence of the relationship between CKD and cardiovascular complication.

Because hypertension in CKD is predominantly systolic [33], we explored the relationship between systolic blood pressure (BP) with ECG abnormalities in a cross-sectional study. In our logistic regression models, only systolic BP is associated with ECG abnormalities (QTc interval prolongation or fragmented QRS, or both). The severity of diastolic dysfunction in CKD usually progressed (from grade I to grade III) with the rise in systolic BP readings. The presence of diastolic dysfunction itself also the risk factor to develop any ECG abnormalities. We did not find an association between diastolic BP with ECG abnormalities, even in bivariate analysis, regardless of BP technique. One possible reason for the lack of association between diastolic BP with ECG abnormalities maybe because the mean diastolic BP in our study population is nearly normal. In perspective, the differences between predictors of systolic BP and diastolic BP might be explainable [34].

Our study suffers from many limitations. Firstly, further risk factors for ECG abnormalities were not taken into account for the analysis. Secondly, this was a cross-sectional study, single-center with small sample sizes in once measurement and therefore we cannot imply causality from association studies. Thirdly, necessary information such as echocardiography or chest x-ray may be unavailable. Fourthly, we did not have data on medications that may have influenced cardiovascular parameters in this study. Fifthly, the interpretation of several laboratories and clinical parameters changes over time. For example, serum creatinine is a breakdown product of muscle, its level is directly associated with muscle mass, which is lower in the elderly, women and whites[35]. The strength of this study was that data already exists, prevalence estimation could be done at one point in time, complete study populations minimizing selection bias and independently collected data. 


\section{CONCLUSION}

In hospitalized CKD patients, ECG abnormalities are common, where fragmented QRS and prolonged QTc were the most prevalent ECG abnormalities. Serum creatinine and hemoglobin could predict peaked T wave and prolonged QTC among hospitalized CKD patients. Systolic blood pressure could predict prolonged QTc and fragmented QRS in CKD patients. Longitudinal studies are needed to show the causality of each parameter with ECG abnormalities.

Ethical Clearance: Dr. Soetomo General Academic Hospital conferred ethical clearance for this study. Compliance with ethical standards, this research proposal was approved by the ethical committees of Dr. Soetomo General Academic Hospital in collaboration with Universitas Airlangga College of Medicine Research Ethics Council (Ref: 1811/KEPK/II/2020) under the name of Rerdin Julario as the Principal Investigator.

Conflict of Interest: None declared

Funding: None declared

Availability of Data and Material: The datasets generated during and/or analyzed during the current study are not publicly available due to protecting participant confidentiality but are available from the corresponding author on reasonable request.

Acknowledgment: The authors would also like to offer special thanks to all staff, fellows, residents, and nurses from the Department of Cardiology and Vascular Medicine \& Divison of Nephrology Department of Medicine, Dr. Soetomo Academic General Hospital, Surabaya for their technical contribution.

Data Availability Statements: The datasets generated and analyzed during this study are not publicly available but are available by contacting the corresponding author.

Author Contribution: R.J. conceived the idea. R.A.N. designed the research and initially wrote the manuscript. B.P.D.K. and T.S.P. carried out the observations. E.P.B.M. helped the project administration. R.E.I. analyzed and interpreted the data, developed the model formulation. F.F.A. helped draft and reviewed the manuscript. All authors read and approved the final version of the manuscript.

Provenance and peer review: Not commissioned; externally peer reviewed. 
medRxiv preprint doi: https://doi.org/10.1101/2021.01.15.21249916; this version posted January 20, 2021. The copyright holder for this preprint (which was not certified by peer review) is the author/funder, who has granted medRxiv a license to display the preprint in perpetuity.

All rights reserved. No reuse allowed without permission.

\section{References}

[1] Shastri S, Sarnak MJ. Cardiovascular Disease and CKD: Core Curriculum 2010. Am J Kidney Dis 2010; 56: 399-417.

[2] KDIGO. KDIGO 2017 Clinical Practice Guideline Update for the Diagnosis, Evaluation, Prevention, and Treatment of Chronic Kidney Disease-Mineral and Bone Disorder (CKD-MBD). Kidney Int Suppl 2017; 7: 1-59.

[3] Lunney M, Alrukhaimi M, Ashuntantang GE, et al. Guidelines, policies, and barriers to kidney care: findings from a global survey. Kidney Int Suppl 2018; 8: 30-40.

[4] Fink JC, Brown J, Hsu VD, et al. CKD as an underrecognized threat to patient safety. Am J Kidney Dis 2009; 53: 681-8.

[5] Saeed ZI, Hussain SA. Chronic kidney disease in Pakistan: an under-recognized public health problem. Kidney Int 2012; 81: 1151; author reply 1151-2.

[6] Jayanti A, Foden P, Mitra S. Multidisciplinary staff attitudes to home haemodialysis therapy. Clin Kidney J 2017; 10: 269-275.

[7] Shafi S, Saleem M, Anjum R, et al. ECG Abnormalities In Patients With Chronic Kidney Disease. J Ayub Med Coll Abbottabad 2017; 29: 61-64.

[8] Levey AS, Stevens LA. Estimating GFR using the CKD Epidemiology Collaboration (CKD-EPI) creatinine equation: more accurate GFR estimates, lower CKD prevalence estimates, and better risk predictions. Am J Kidney Dis 2010; 55: 622-7.

[9] Hung TW, Huang JY, Jong GP. Long-term outcomes of dialysis in patients with chronic kidney disease and new-onset atrial fibrillation: A population-based cohort study. PLoS One 2019; 14: 110.

[10] Liu M, Li XC, Lu L, et al. Cardiovascular disease and its relationship with chronic kidney disease. Eur Rev Med Pharmacol Sci 2014; 18: 2918-2926.

[11] Drosos G, Ampatzidou F, Sarafidis P, et al. Serum Creatinine and Chronic Kidney DiseaseEpidemiology Estimated Glomerular Filtration Rate: Independent Predictors of Renal Replacement Therapy following Cardiac Surgery. Am J Nephrol 2018; 48: 108-117.

[12] Adeoye AM, Adebayo O, Abiola O, et al. Association between Selected Molecular BiOmarkers and AmbuLatory Blood Pressure Pattern in African Chronic Kidney Disease and Hypertensive Patients compared with normotenslve Controls: The SyMBOLIC Study Protocol (Preprint). JMIR Res Protoc 2019; 9: 1-8.

[13] Chen SC, Huang JC, Su HM, et al. Prognostic cardiovascular markers in chronic kidney disease. Kidney Blood Press Res 2018; 43: 1388-1407.

[14] Leoncini G, Viazzi F, Parodi D, et al. Creatinine clearance and signs of end-organ damage in primary hypertension. J Hum Hypertens 2004; 18: 511-516.

[15] Shirafkan A, Motahari M, Mojerlou M, et al. Association between left ventricular hypertrophy with retinopathy and renal dysfunction in patients with essential hypertension. Singapore Med J 
medRxiv preprint doi: https://doi.org/10.1101/2021.01.15.21249916; this version posted January 20, 2021. The copyright holder for this preprint (which was not certified by peer review) is the author/funder, who has granted medRxiv a license to display the preprint in perpetuity.

All rights reserved. No reuse allowed without permission.

2009; 50: 1177-1183.

[16] El-Sherif N, Turitto G. Electrolyte disorders and arrhythmogenesis. Cardiol J 2011; 18: 233-245.

[17] Levis JT. CLINICAL MEDICINE ECG Diagnosis : Hyperkalemia. Perm Journal 2013; 17: 69.

[18] Cobo Sánchez JL, Alconero Camarero AR, Casaus Pérez M, et al. Hyperkalaemia and haemodialysis patients: Electrocardiographic changes. J Ren Care 2007; 33: 124-129.

[19] Aslam S, Friedman EA, Ifudu O. EKG is Unreliable in Detecting Potentially Lethal Hyperkalemia in Hemodialysis (HD) Patients. ASAIO J 2001; 47: 158.

[20] Sharma S, Gupta H, Ghosh M, et al. Severe hyperkalemia with normal electrocardiogram. Indian J Crit Care Med 2007; 11: 215-217.

[21] Liu P, Han D, Sun X, et al. Prevalence and risk factors of acquired long QT syndrome in hospitalized patients with chronic kidney disease. J Investig Med 2019; 67: 289-294.

[22] Bodi I, Grünert SC, Becker N, et al. Mechanisms of acquired long QT syndrome in patients with propionic academia. Hear Rhythm 2016; 13: 1335-1345.

[23] Kalantar-Zadeh K, Aronoff GR. Hemoglobin variability in anemia of chronic kidney disease. J Am Soc Nephrol 2009; 20: 479-487.

[24] Ponikowski P, Van Veldhuisen DJ, Comin-Colet J, et al. Beneficial effects of long-term intravenous iron therapy with ferric carboxymaltose in patients with symptomatic heart failure and iron deficiency. Eur Heart J 2015; 36: 657-668.

[25] Lewis GD, Malhotra R, Hernandez AF, et al. Effect of oral iron repletion on exercise capacity in patients with heart failure with reduced ejection fraction and iron deficiency the IRONOUT HF randomized clinical trial. JAMA - J Am Med Assoc 2017; 317: 1958-1966.

[26] Muzzarelli S, Pfisterer M. Anemia as independent predictor of major events in elderly patients with chronic angina. Am Heart J 2006; 152: 991-996.

[27] Armstrong PW, Fu Y, Chang WC, et al. Acute coronary syndromes in the GUSTO-IIb trial: Prognostic insights and impact of recurrent ischemia. Circulation 1998; 98: 1860-1868.

[28] Harrington RA. PATIENTS WITH ACUTE CORONARY SYNDROMES.

[29] Harrington RA. Randomized, placebo-controlled trial of titrated intravenous lamifiban for acute coronary syndromes. Circulation 2002; 105: 316-321.

[30] Go AS, Yang J, Ackerson LM, et al. Hemoglobin level, chronic kidney disease, and the risks of death and hospitalization in adults with chronic heart failure - The anemia in chronic heart failure: Outcomes and Resource Utilization (ANCHOR) Study. Circulation 2006; 113: 2713-2723.

[31] Sarnak MJ, Tighiouart H, Manjunath G, et al. Anemia as a risk factor for cardiovascular disease in the Atherosclerosis Risk in Communities (ARIC) study. J Am Coll Cardiol 2002; 40: 27-33.

[32] Rymer JA, Rao S V. Anemia and coronary artery disease: Pathophysiology, prognosis, and treatment. Coron Artery Dis 2018; 29: 161-167.

[33] Andersen MJ, Khawandi W, Agarwal R. Home blood pressure monitoring in CKD. Am J Kidney Dis 2005; 45: 994-1001. 
medRxiv preprint doi: https://doi.org/10.1101/2021.01.15.21249916; this version posted January 20, 2021. The copyright holder for this preprint (which was not certified by peer review) is the author/funder, who has granted medRxiv a license to display the preprint in perpetuity.

All rights reserved. No reuse allowed without permission.

[34] Agarwal R, Andersen MJ. Correlates of systolic hypertension in patients with chronic kidney disease. Hypertension 2005; 46: 514-520.

[35] Bargnoux A-S, Kuster N, Cavalier E, et al. Serum creatinine: advantages and pitfalls. J Lab Precis Med 2018; 3: 71-71.

[36] Lilly LS. Pathophysiology of Heart Disease. 6th ed. Philadelphia: Wolters Kluwer -- Medknow Publications, 2016.

[37] Take Y, Morita H. Fragmented QRS: What Is The Meaning? Indian Pacing Electrophysiol J 2012; 12: 213.

[38] Surawicz B, Childers R, Deal BJ, et al. AHA/ACCF/HRS Recommendations for the Standardization and Interpretation of the Electrocardiogram: Part III: Intraventricular Conduction Disturbances A Scientific Statement From the American Heart Association Electrocardiography and Arrhythmias Committee, . J Am Coll Cardiol 2009; 53: 976-981.

[39] Kim S-H, Kwak MH, Kim HJ, et al. Prevalence and positive predictive value of poor R-wave progression and impact of the cardiothoracic ratio. Korean Circ J 2009; 39: 418-22.

[40] Tsao CW, Josephson ME, Hauser TH, et al. Accuracy of electrocardiographic criteria for atrial enlargement: validation with cardiovascular magnetic resonance. J Cardiovasc Magn Reson 2008; 10: 7.

[41] Sklyar E, Ginelli P, Barton A, et al. Validity of electrocardiographic criteria for increased left ventricular mass in young patients in the general population. World J Cardiol 2017; 9: 248-254.

[42] Whitman IR, Patel V V, Soliman EZ, et al. Validity of the surface electrocardiogram criteria for right ventricular hypertrophy: the MESA-RV Study (Multi-Ethnic Study of Atherosclerosis-Right Ventricle). J Am Coll Cardiol 2014; 63: 672-681.

[43] Ibanez B, James S, Agewall S, et al. 2017 ESC Guidelines for the management of acute myocardial infarction in patients presenting with ST-segment elevation. Eur Heart J 2018; 39: 119-177.

[44] Hanna EB, Glancy DL. ST-segment depression and T-wave inversion: Classification, differential diagnosis, and caveats | Cleveland Clinic Journal of Medicine. Cleve Clin J Med 2011; 78: 404-414.

[45] Bao H, Cai H, Zhao Y, et al. Nonspecific ST-T changes associated with unsatisfactory blood pressure control among adults with hypertension in China: Evidence from the CSPPT study. Medicine (Baltimore) 2017; 96: e6423.

[46] Arjmand A, Eshraghi A, Sani ZA, et al. Value of pathologic Q wave in surface electrocardiography in the prediction of myocardial nonviability: A cardiac magnetic resonance imaging-based study. $J$ Adv Pharm Technol Res 2018; 9: 162.

[47] Pappal R, Espina I, Rafique Z. Peaked T-Waves and Potassium: The Reliability of Peaked T-Waves as Indicators of Hyperkalemia in End-Stage Renal Patients Undergoing Hemodialysis. Am J Undergrad Res; 13. Epub ahead of print August 2016. DOI: 10.33697/ajur.2016.027.

[48] Andrianto A, Dewi PR. Clinical Implications of Low-voltage Electrocardiogram. Indones J Cardiol 2017; 206-12. 
medRxiv preprint doi: https://doi.org/10.1101/2021.01.15.21249916; this version posted January 20, 2021. The copyright holder for this preprint (which was not certified by peer review) is the author/funder, who has granted medRxiv a license to display the preprint in perpetuity.

All rights reserved. No reuse allowed without permission.

\section{TABLES}

Table 1. Normal limit of ECG parameters

\begin{tabular}{ll}
\hline \multicolumn{1}{c}{ Parameters } & \multicolumn{1}{c}{ Normal Limit } \\
\hline Rhythm & Sinus rhythm (Positive P wave in I, II, aVF and no AV dissociation) [36] \\
\hline Heart rate & $60-100$ beat per minute (bpm) [36] \\
\hline Frontal axis & $-30-+90^{\circ}[36]$ \\
\hline P wave & $<120$ miliseconds (ms) in duration and $<2,5 \mathrm{~mm}$ in amplitude [36] \\
\hline PR interval & $120-200 \mathrm{~ms} \mathrm{[36]}$ \\
\hline QRS complex & $<120 \mathrm{~ms}$ and no fragmented QRS [36] \\
\hline Q wave & Depth $<1 / 4$ amplitude deflection of R wave and $\leq 40 \mathrm{~ms} \mathrm{[36]}$ \\
\hline QT interval & QTc by Bazzet's formula 330 $-440 \mathrm{~ms}$ in male or 330 - 450 in female [36] \\
\hline ST-segment & Deviation at J-point $<1 \mathrm{~mm}$ [36] \\
\hline T wave & No inverted T wave except in III, aVR, V1 [36] \\
\hline
\end{tabular}


Table 2. Definition used for ECG abnormality

\begin{tabular}{ll}
\hline \multicolumn{1}{c}{ ECG Abnormality } & \multicolumn{1}{c}{ Definition Used } \\
\hline Fragmented QRS (fQRS) & additional spikes within the QRS complex [37] \\
\hline Left bundle branch & 1) QRS duration greater than or equal to $120 \mathrm{~ms}, 2$ ) Broad notched or \\
block (LBBB) & $\begin{array}{l}\text { slurred R wave in leads I, aVL, V5, and V6 and an occasional RS pattern } \\
\text { in V5 and V6 attributed to displaced transition of QRS complex, 3) }\end{array}$ \\
& Absent q waves in leads I, V5, and V6, but in the lead aVL, a narrow q \\
& wave may be present in the absence of myocardial pathology, 4) R \\
& peak time greater than 60 ms in leads V5and V6but normal in leads V1, \\
& V2, and V3, when small initial r waves can be discerned in the above \\
& leads, 5) ST and T waves usually opposite in direction to QRS, 6) \\
& Positive T wave in leads with upright QRS may be normal (positive \\
& concordance), 7) Depressed ST segment and/or negative T wave in \\
& leads with negative QRS (negative concordance) are abnormal and are \\
& discussed in part VI of this statement, 8) The appearance of LBBB may \\
& change the mean QRS axis in the frontal plane to the right, to the left, \\
& or to a superior, in some cases in a rate-dependent manner [38]
\end{tabular}

Right bundle branch 1 1) QRS duration was greater than or equal to $120 \mathrm{~ms}, 2) r s r^{\prime}, r s^{\prime}$, or block (RBBB) $\quad r S R^{\prime}$ in leads V1or V2. The $R^{\prime}$ or $r^{\prime}$ deflection is usually wider than the initial $R$ wave. In a minority of patients, a wide and often notched $R$ wave pattern may be seen in lead V1and/or V2. S wave of greater duration than $\mathrm{R}$ wave or greater than $40 \mathrm{~ms}$ in leads I and V6. Normal $\mathrm{R}$ peak time in leads V5 and V6 but greater than $50 \mathrm{~ms}$ in lead V1 [38]

\begin{tabular}{|c|c|}
\hline $\begin{array}{l}\text { Poor R wave } \\
\text { progression (PRWP) }\end{array}$ & R-wave in V3 or V4 $\leq 2 \mathrm{~mm}[39]$ \\
\hline $\begin{array}{l}\text { Left atrial enlargement } \\
\text { (LAE) }\end{array}$ & $\begin{array}{l}\text { any one of the following: } 1 \text { ) } P \text { wave in any lead }>0.11 \mathrm{~s}, 2) \text { Notched } P \\
\text { wave with interpeak duration }>0.04 \mathrm{~s}\left(\mathrm{P} \text { mitrale), 3) } \mathrm{P} \text { wave axis }<30^{\circ} \text {, }\right. \\
\text { 4) Area of negative } P \text { terminal force in lead V1 (NPTF-V1) }>0.04 \mathrm{~s} \cdot \mathrm{mm} \text {, } \\
\text { or 5) Positive } P \text { terminal force in aVL (PPTF-aVL) }>0.5 \mathrm{~mm}[40]\end{array}$ \\
\hline $\begin{array}{l}\text { left ventricular } \\
\text { hypertrophy (LVH) }\end{array}$ & $\begin{array}{l}\text { Sokolow-Lyon voltage criteria: the amplitude of the S wave in lead V1 } \\
\text { was added to the largest amplitude of the R wave in either lead V5 or } \\
\text { V6, with a value greater than or equal to } 35 \mathrm{~mm} \text { meeting criteria for } \\
\text { LVH [41] }\end{array}$ \\
\hline $\begin{array}{l}\text { Right atrial enlargement } \\
\text { (RAE) }\end{array}$ & $\begin{array}{l}\text { Any one of the following: 1) P wave in inferior leads II, III, aVF }>2.5 \mathrm{~mm} \\
\text { or 2) Positive P wave in V1 > } 1.5 \mathrm{~mm} \text { [40] }\end{array}$ \\
\hline $\begin{array}{l}\text { Right ventricular } \\
\text { hypertrophy (RVH) }\end{array}$ & $\begin{array}{l}\text { Myers criteria, any one of the following: Tall R V1 }>6 \mathrm{mV} \text {, increased R:S } \\
\text { ratio V1 }>1.0 \text {, Deep S V5 }>10 \mathrm{mV} \text {, Deep S V } 63 \mathrm{mV} \text {, Small S V1 }<2 \\
\mathrm{mV} \text {, Small R V5,6 }<3 \mathrm{mV} \text {, Reduced R:S ratio V } 5<0.75 \text {, Reduced R:S } \\
\text { ratio V6 }<0.4 \text {, R peak V1 (QRS duration }<0.12 \mathrm{sec} \text { ) }>0.035 \text {, Presence of } \\
\text { QR V1 [42] }\end{array}$ \\
\hline ST-elevation & $\begin{array}{l}\text { two contiguous leads with ST-segment elevation } \geq 2.5 \mathrm{~mm} \text { in men }< \\
40 \text { years, } \geq 2 \mathrm{~mm} \text { in men } \geq 40 \text { years, or } \geq 1.5 \mathrm{~mm} \text { in women in leads } \mathrm{V}_{2}- \\
\mathrm{V}_{3} \text { and/or } \geq 1 \mathrm{~mm} \text { in the other leads (in the absence of left ventricular } \\
\text { (LV) hypertrophy or left bundle branch block LBBB) [43] }\end{array}$ \\
\hline ST-depression & depression of the ST-segment of $\geq 0.05 \mathrm{mV}$ below the isoelectric line in \\
\hline
\end{tabular}


medRxiv preprint doi: https://doi.org/10.1101/2021.01.15.21249916; this version posted January 20, 2021. The copyright holder for this preprint (which was not certified by peer review) is the author/funder, who has granted medRxiv a license to display the preprint in perpetuity.

All rights reserved. No reuse allowed without permission.

leads V2 and V3 and $\geq 0.1 \mathrm{mV}$ in the other lead [44]

\begin{tabular}{|c|c|}
\hline Inverted T wave & Inverted T wave deeper than $1 \mathrm{~mm} \mathrm{[44]}$ \\
\hline $\begin{array}{l}\text { Non-specific ST-T (NS- } \\
\text { STT) changes }\end{array}$ & 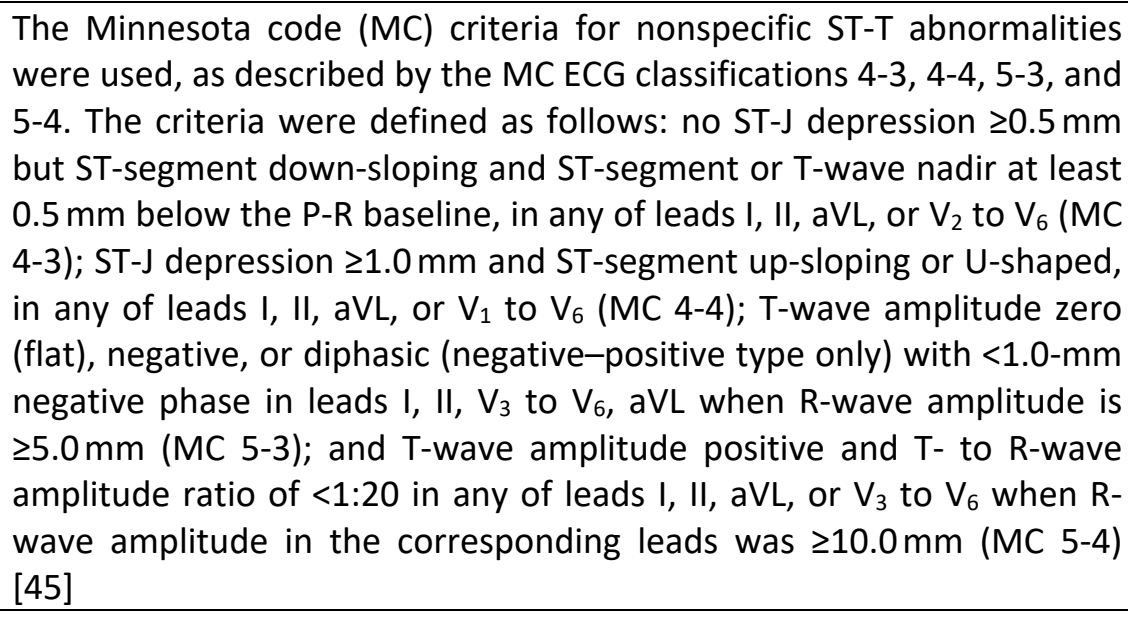 \\
\hline Pathologic Q wave & $\begin{array}{l}\text { any } Q \text { wave with more than } 40 \mathrm{~ms} \text { width or a depth more than one- } \\
\text { third of the adjacent } R \text { wave in more than two adjacent leads [46] }\end{array}$ \\
\hline Peaked T wave & $\begin{array}{l}\text { subjective assessment of peaked } T \text { wave morphology (narrow, } \\
\text { symmetric, and tall } T \text { wave or } T / R \text { ratio } \geq 0.75 \text { ) [47] }\end{array}$ \\
\hline Low voltage & $\begin{array}{l}\text { peak-to-peak QRS voltage less than } 5 \mathrm{~mm} \text { in all limb leads and less than } \\
10 \mathrm{~mm} \text { in all precordial leads [48] }\end{array}$ \\
\hline
\end{tabular}


medRxiv preprint doi: https://doi.org/10.1101/2021.01.15.21249916; this version posted January 20, 2021. The copyright holder for this preprint (which was not certified by peer review) is the author/funder, who has granted medRxiv a license to display the preprint in perpetuity.

All rights reserved. No reuse allowed without permission.

Table 3. Baseline characteristic of study population

\begin{tabular}{|c|c|c|}
\hline Variables & N (198) & Proportion (\%) \\
\hline \multicolumn{3}{|l|}{ Age Range } \\
\hline$<=30$ & 10 & $5.1 \%$ \\
\hline $31-40$ & 25 & $12.6 \%$ \\
\hline $41-50$ & 39 & $19.7 \%$ \\
\hline $51-60$ & 79 & $39.9 \%$ \\
\hline $61-70$ & 35 & $17.7 \%$ \\
\hline$>70$ & 10 & $5.1 \%$ \\
\hline \multicolumn{3}{|l|}{ Sex } \\
\hline Male & 101 & $51 \%$ \\
\hline Female & 97 & $49 \%$ \\
\hline \multicolumn{3}{|l|}{ Comorbidities } \\
\hline Anemia & 143 & $72.2 \%$ \\
\hline HTN & 111 & $56.1 \%$ \\
\hline Diabetes Mellitus & 75 & $37.9 \%$ \\
\hline Metabolic Acidosis & 63 & $31.8 \%$ \\
\hline Pneumonia & 48 & $24.2 \%$ \\
\hline Hypoalbuminemia & 48 & $24.2 \%$ \\
\hline Hyponatremia & 38 & $19.2 \%$ \\
\hline Pleural Effusion & 30 & $15.2 \%$ \\
\hline Pulmonary Edema & 29 & $14.7 \%$ \\
\hline CVD, others & 16 & $8.1 \%$ \\
\hline Nephrolithiasis & 14 & $7.1 \%$ \\
\hline Heart Failure & 6 & $3.0 \%$ \\
\hline Coronary Artery Disease & 1 & $0.5 \%$ \\
\hline Pericardial Effusion & 1 & $0.5 \%$ \\
\hline \multicolumn{3}{|l|}{$\begin{array}{l}\text { GFR } \mathrm{mL} / \mathrm{min} / 1.73 \mathrm{~m}^{2} \text { (CKD } \\
\text { stage) }\end{array}$} \\
\hline$>89$ (stage 1$)$ & 1 & $0.5 \%$ \\
\hline $60-89$ (stage 2 ) & 2 & $1 \%$ \\
\hline 45-59 (stage 3A) & 2 & $1 \%$ \\
\hline 30-44 (stage 3B) & 9 & $4.6 \%$ \\
\hline 15-29 (stage 4) & 23 & $11.7 \%$ \\
\hline$<15$ (stage 5) & 160 & $81.22 \%$ \\
\hline \multicolumn{3}{|l|}{ Potassium level (mEq/L) } \\
\hline$<3.5$ & 18 & $9.1 \%$ \\
\hline $3.5-5.0$ & 89 & $44.9 \%$ \\
\hline$>5.0$ & 90 & $45.5 \%$ \\
\hline
\end{tabular}


medRxiv preprint doi: https://doi.org/10.1101/2021.01.15.21249916; this version posted January 20, 2021. The copyright holder for this preprint (which was not certified by peer review) is the author/funder, who has granted medRxiv a license to display the preprint in perpetuity.

All rights reserved. No reuse allowed without permission.

Table 4. ECG Abnormalities

\begin{tabular}{lc}
\hline \multicolumn{1}{c}{ Abnormalities } & N (Proportion) \\
\hline Long QTc & $75(37.9 \%)$ \\
Fragmented QRS complex & $59(29.8 \%)$ \\
Poor Precordial R wave Progression & $48(24.2 \%)$ \\
Left Atrial Enlargement & $46(23.2 \%)$ \\
Peaked T wave & $43(21.7 \%)$ \\
Left Ventricular Hypertrophy & $31(15.6 \%)$ \\
Pathological Q wave & $27(13.6 \%)$ \\
Non-specific ST-T Changes & $26(13.1 \%)$ \\
Frontal Axis Deviation & $21(10.6 \%)$ \\
Inverted T Wave & $14(7.1 \%)$ \\
$1^{\text {st } D e g r e e ~ A V ~ B l o c k ~}$ & $14(7.1 \%)$ \\
ST Segment Depression & $13(6.6 \%)$ \\
Right Bundle Branch Block & $11(5.6 \%)$ \\
Wide QRS Complex & $7(3.5 \%)$ \\
Premature Ventricular Contraction (PVC) & $6(3.0 \%)$ \\
Right Ventricular Hypertrophy & $5(2.5 \%)$ \\
Non-Sinus Rhythm & $4(2.0 \%)$ \\
Low voltage & $3(1.5 \%)$ \\
ST segment elevation & $2(1.0 \%)$ \\
Right Atrial Enlargement & $2(1.0 \%)$ \\
Premature Atrial Contraction (PAC) & $1(0.5 \%)$ \\
Short QTc & $1(0.5 \%)$ \\
Left Bundle Branch Block & $1(0.5 \%)$ \\
$2^{\text {nd }}$ Degree AV Block & $1(0.5 \%)$ \\
\hline
\end{tabular}


medRxiv preprint doi: https://doi.org/10.1101/2021.01.15.21249916; this version posted January 20, 2021. The copyright holder for this preprint (which was not certified by peer review) is the author/funder, who has granted medRxiv a license to display the preprint in perpetuity.

All rights reserved. No reuse allowed without permission.

Table 5. Area under the curve (AUC) of clinical prediction model for age, BUN, serum creatinine, eGFR, systolic blood pressure, diastolic blood pressure, hemoglobin level and serum potassium. Prediction of long QT interval by age, BUN, serum creatinine, eGFR, systolic blood pressure, diastolic blood pressure, hemoglobin level and serum potassium. $P<0.001$ for all ROC curves compared with 0.5 curves.

\begin{tabular}{|c|c|c|c|c|c|}
\hline \multirow[b]{3}{*}{ Test Result Variable(s) } & \multicolumn{3}{|c|}{ Area Under the Curve } & \multirow{2}{*}{\multicolumn{2}{|c|}{$\begin{array}{c}\text { Asymptotic 95\% Confidence } \\
\text { Interval }\end{array}$}} \\
\hline & & & Asymptotic & & \\
\hline & Area & Std. Error ${ }^{a}$ & Sig. ${ }^{\text {b }}$ & Lower Bound & Upper Bound \\
\hline Age & ,518 & ,042 & 672 & ,436 & 600 \\
\hline BUN & ,395 & ,040 & ,013 & 316 & ,475 \\
\hline Creatinin &, 554 & ,042 & 199 & 472 & ,636 \\
\hline eGFR & ,450 & ,042 & ,232 & ,368 & ,532 \\
\hline Systole & ,555 & ,041 & 191 & ,474 & ,636 \\
\hline Diastole &, 540 & ,041 & ,343 & ,459 & ,621 \\
\hline Hemoglobin & ,511 & ,042 & ,799 & ,429 & ,592 \\
\hline Kalium & ,379 & 042 & ,004 & ,296 & ,462 \\
\hline
\end{tabular}

The test result variable(s): Age, BUN, Creatinin, Systole, Diastole, Hemoglobin, Kalium has at least one tie between the positive actual state group and the negative actual state group. Statistics may be biased.

a. Under the nonparametric assumption

b. Null hypothesis: true area $=0.5$ 
medRxiv preprint doi: https://doi.org/10.1101/2021.01.15.21249916; this version posted January 20, 2021. The copyright holder for this preprint (which was not certified by peer review) is the author/funder, who has granted medRxiv a license to display the preprint in perpetuity.

All rights reserved. No reuse allowed without permission.

Table 6. Area under the curve (AUC) of clinical prediction model for age, BUN, serum creatinine, eGFR, systolic blood pressure, diastolic blood pressure, hemoglobin level and serum potassium. Prediction of fragmented QRS by age, BUN, serum creatinine, eGFR, systolic blood pressure, diastolic blood pressure, hemoglobin level and serum potassium. $P<0.001$ for all ROC curves compared with 0.5 curves.

\begin{tabular}{|c|c|c|c|c|c|}
\hline \multirow[b]{3}{*}{ Test Result Variable(s) } & \multicolumn{3}{|c|}{ Area Under the Curve } & \multirow{2}{*}{\multicolumn{2}{|c|}{$\begin{array}{c}\text { Asymptotic 95\% Confidence } \\
\text { Interval }\end{array}$}} \\
\hline & & & Asymptotic & & \\
\hline & Area & Std. Error ${ }^{a}$ & Sig. ${ }^{\mathrm{b}}$ & Lower Bound & Upper Bound \\
\hline Age & ,502 & ,045 & ,964 & ,413 & ,591 \\
\hline BUN & ,473 & ,046 & ,553 & ,384 & ,563 \\
\hline Creatinin & ,500 & ,046 & 1,000 & ,410 & ,590 \\
\hline eGFR & ,502 & ,046 & ,969 & ,411 & ,592 \\
\hline Systole & ,532 & ,048 & ,478 & ,439 & ,626 \\
\hline Diastole & ,476 & ,048 & ,589 & ,381 & ,570 \\
\hline Hemoglobin & ,545 & ,046 & ,321 & ,455 & ,635 \\
\hline Kalium & ,496 & ,047 & 926 & ,405 & ,587 \\
\hline
\end{tabular}

The test result variable(s): Age, BUN, Creatinin, Systole, Diastole, Hemoglobin, Kalium has at least one tie between the positive actual state group and the negative actual state group. Statistics may be biased.

a. Under the nonparametric assumption

b. Null hypothesis: true area $=0.5$ 
medRxiv preprint doi: https://doi.org/10.1101/2021.01.15.21249916; this version posted January 20, 2021. The copyright holder for this preprint (which was not certified by peer review) is the author/funder, who has granted medRxiv a license to display the preprint in perpetuity.

All rights reserved. No reuse allowed without permission.

Table 7. Area under the curve (AUC) of clinical prediction model for age, BUN, serum creatinine, eGFR, systolic blood pressure, diastolic blood pressure, hemoglobin level and serum potassium. Prediction of LVH by age, BUN, serum creatinine, eGFR, systolic blood pressure, diastolic blood pressure, hemoglobin level and serum potassium. $P<0.001$ for all ROC curves compared with 0.5 curves.

\begin{tabular}{|c|c|c|c|c|c|}
\hline \multirow[b]{3}{*}{ Test Result Variable(s) } & \multicolumn{3}{|c|}{ Area Under the Curve } & \multirow{2}{*}{\multicolumn{2}{|c|}{$\begin{array}{l}\text { Asymptotic 95\% Confidence } \\
\text { Interval }\end{array}$}} \\
\hline & & & Asymptotic & & \\
\hline & Area & Std. Error ${ }^{a}$ & Sig. ${ }^{\mathrm{b}}$ & Lower Bound & Upper Bound \\
\hline Age &, 519 &, 061 & ,733 & ,399 & ,639 \\
\hline BUN & ,402 & ,057 & ,080 & ,290 & ,514 \\
\hline Creatinin & ,634 & , 048 & ,017 & ,540 & ,728 \\
\hline eGFR & ,388 & , 050 & ,046 & ,291 & 486 \\
\hline Systole & ,578 & ,052 & ,162 & ,475 & 681 \\
\hline Diastole & ,622 & ,050 & 029 & ,524 & ,720 \\
\hline Hemoglobin & ,447 & ,052 & ,347 & ,345 &, 550 \\
\hline Kalium & ,467 & 055 & ,551 & ,359 & ,574 \\
\hline
\end{tabular}

The test result variable(s): Age, BUN, Creatinin, Systole, Diastole, Hemoglobin, Kalium has at least one tie between the positive actual state group and the negative actual state group. Statistics may be biased.

a. Under the nonparametric assumption

b. Null hypothesis: true area $=0.5$ 
medRxiv preprint doi: https://doi.org/10.1101/2021.01.15.21249916; this version posted January 20, 2021. The copyright holder for this preprint (which was not certified by peer review) is the author/funder, who has granted medRxiv a license to display the preprint in perpetuity.

All rights reserved. No reuse allowed without permission.

Table 8. Area under the curve (AUC) of clinical prediction model for age, BUN, serum creatinine, eGFR, systolic blood pressure, diastolic blood pressure, hemoglobin level and serum potassium. Prediction of peaked T wave by age, BUN, serum creatinine, eGFR, systolic blood pressure, diastolic blood pressure, hemoglobin level and serum potassium. $P<0.001$ for all ROC curves compared with 0.5 curves.

\begin{tabular}{|c|c|c|c|c|c|}
\hline \multirow[b]{3}{*}{ Test Result Variable(s) } & \multirow[b]{3}{*}{ Area } & \multicolumn{4}{|c|}{ Area Under the Curve } \\
\hline & & \multirow[b]{2}{*}{ Std. Error ${ }^{\mathrm{a}}$} & \multirow[b]{2}{*}{ Asymptotic Sig. ${ }^{\mathrm{b}}$} & \multicolumn{2}{|c|}{$\begin{array}{c}\text { Asymptotic 95\% Confidence } \\
\text { Interval }\end{array}$} \\
\hline & & & & Lower Bound & Upper Bound \\
\hline Age &, 564 & ,048 & ,201 & ,469 & ,658 \\
\hline BUN & ,430 &, 048 & , 163 & ,337 &, 524 \\
\hline Creatinin & ,707 &, 047 &, 000 & ,616 & ,798 \\
\hline eGFR & ,303 &, 048 & ,000 & ,209 & ,398 \\
\hline Systole &, 545 & ,048 & ,370 &, 451 & 639 \\
\hline Diastole &, 566 & ,049 & ,189 & ,469 & ,662 \\
\hline Hemoglobin & ,447 &, 050 & ,286 & ,348 &, 545 \\
\hline Kalium & ,688 &, 044 &, 000 & ,601 &, 775 \\
\hline
\end{tabular}

The test result variable(s): Age, BUN, Creatinin, Systole, Diastole, Hemoglobin, Kalium has at least one tie between the positive actual state group and the negative actual state group. Statistics may be biased.

a. Under the nonparametric assumption

b. Null hypothesis: true area $=0.5$ 
medRxiv preprint doi: https://doi.org/10.1101/2021.01.15.21249916; this version posted January 20, 2021. The copyright holder for this preprint (which was not certified by peer review) is the author/funder, who has granted medRxiv a license to display the preprint in perpetuity.

All rights reserved. No reuse allowed without permission.

Table 9. Area under the curve (AUC) of clinical prediction model for age, BUN, serum creatinine, eGFR, systolic blood pressure, diastolic blood pressure, hemoglobin level and serum potassium. Prediction of poor precordial R wave progression by age, BUN, serum creatinine, eGFR, systolic blood pressure, diastolic blood pressure, hemoglobin level and serum potassium. $P<0.001$ for all ROC curves compared with 0.5 curves.

\begin{tabular}{|c|c|c|c|c|c|}
\hline \multirow[b]{3}{*}{ Test Result Variable(s) } & \multicolumn{3}{|c|}{ Area Under the Curve } & \multirow{2}{*}{\multicolumn{2}{|c|}{$\begin{array}{c}\text { Asymptotic } 95 \% \text { Confidence } \\
\text { Interval }\end{array}$}} \\
\hline & & & Asymptotic & & \\
\hline & Area & Std. Error ${ }^{a}$ & Sig. ${ }^{b}$ & Lower Bound & Upper Bound \\
\hline Age &, 431 & ,047 & 148 & ,338 & ,523 \\
\hline BUN & 497 & ,048 & 957 & ,404 & ,591 \\
\hline Creatinin & ,464 & ,045 & 449 & ,376 &, 551 \\
\hline eGFR & ,517 & ,046 & ,725 & ,427 & ,606 \\
\hline Systole &, 523 & 050 & 629 & ,426 & 621 \\
\hline Diastole & ,479 & ,048 & 655 & ,385 & ,572 \\
\hline Hemoglobin & ,532 & ,047 & ,504 & ,439 & ,625 \\
\hline Kalium & ,491 & ,051 & 846 & ,391 &, 590 \\
\hline
\end{tabular}

The test result variable(s): Age, BUN, Creatinin, Systole, Diastole, Hemoglobin, Kalium has at least one tie between the positive actual state group and the negative actual state group. Statistics may be biased.

a. Under the nonparametric assumption

b. Null hypothesis: true area $=0.5$ 
medRxiv preprint doi: https://doi.org/10.1101/2021.01.15.21249916; this version posted January 20, 2021. The copyright holder for this preprint (which was not certified by peer review) is the author/funder, who has granted medRxiv a license to display the preprint in perpetuity.

All rights reserved. No reuse allowed without permission.

Table 10. Area under the curve (AUC) of clinical prediction model for age, BUN, serum creatinine, eGFR, systolic blood pressure, diastolic blood pressure, hemoglobin level and serum potassium. Prediction of pathological Q wave by age, BUN, serum creatinine, eGFR, systolic blood pressure, diastolic blood pressure, hemoglobin level and serum potassium. $P<0.001$ for all ROC curves compared with 0.5 curves.

\begin{tabular}{|c|c|c|c|c|c|}
\hline \multicolumn{6}{|c|}{ Area Under the Curve } \\
\hline \multirow[b]{2}{*}{ Test Result Variable(s) } & \multirow[b]{2}{*}{ Area } & \multirow[b]{2}{*}{ Std. Error ${ }^{a}$} & \multirow{2}{*}{$\begin{array}{l}\text { Asymptotic } \\
\text { Sig. }\end{array}$} & \multicolumn{2}{|c|}{$\begin{array}{c}\text { Asymptotic 95\% Confidence } \\
\text { Interval }\end{array}$} \\
\hline & & & & Lower Bound & Upper Bound \\
\hline Age & ,389 & ,058 & ,060 & ,276 & ,502 \\
\hline BUN & ,567 & 055 & ,260 & ,459 & ,674 \\
\hline Creatinin & ,397 & ,052 & ,082 & ,295 & ,499 \\
\hline eGFR & ,595 & ,053 & ,106 & ,492 & ,699 \\
\hline Systole & ,526 & ,059 & ,655 & ,411 & ,641 \\
\hline Diastole & ,516 & ,055 & ,783 & ,408 & ,624 \\
\hline Hemoglobin & ,641 & ,061 & 017 &, 521 & ,760 \\
\hline Kalium & ,482 & ,063 & ,758 & ,359 & ,605 \\
\hline
\end{tabular}

The test result variable(s): Age, BUN, Creatinin, Systole, Diastole, Hemoglobin, Kalium has at least one tie between the positive actual state group and the negative actual state group. Statistics may be biased.

a. Under the nonparametric assumption

b. Null hypothesis: true area $=0.5$ 
medRxiv preprint doi: https://doi.org/10.1101/2021.01.15.21249916; this version posted January 20, 2021. The copyright holder for this preprint (which was not certified by peer review) is the author/funder, who has granted medRxiv a license to display the preprint in perpetuity.

All rights reserved. No reuse allowed without permission.

Table 11. Area under the curve (AUC) of clinical prediction model for age, BUN, serum creatinine, eGFR, systolic blood pressure, diastolic blood pressure, hemoglobin level and serum potassium. Prediction of non-specific ST-T changes by age, BUN, serum creatinine, eGFR, systolic blood pressure, diastolic blood pressure, hemoglobin level and serum potassium. $P<0.001$ for all ROC curves compared with 0.5 curves.

\begin{tabular}{lr|r|r|r|r} 
& & \multicolumn{3}{c}{ Area Under the Curve } & \multicolumn{2}{c}{$\begin{array}{c}\text { Asymptotic 95\% Confidence } \\
\text { Interval }\end{array}$} \\
\hline Test Result Variable(s) & Area & Std. Error & $\begin{array}{r}\text { Asymptotic } \\
\text { Sig. }\end{array}$ & \multicolumn{2}{c}{$\begin{array}{c}\text { Lower Bound } \\
\text { Upper Bound }\end{array}$} \\
\hline Age &, 422 &, 061 &, 199 &, 303 &, 541 \\
\hline BUN &, 485 &, 066 &, 811 &, 356 &, 614 \\
\hline Creatinin &, 406 &, 058 &, 123 &, 292 &, 521 \\
\hline eGFR &, 594 &, 058 &, 123 &, 481 &, 707 \\
\hline Systole &, 521 &, 060 &, 729 &, 403 &, 639 \\
\hline Diastole &, 494 &, 059 &, 916 &, 377 &, 610 \\
\hline Hemoglobin &, 556 &, 053 &, 362 &, 451 &, 660 \\
\hline Kalium &, 468 &, 060 &, 603 &, 351 &, 586 \\
\hline
\end{tabular}

The test result variable(s): Age, BUN, Creatinin, Systole, Diastole, Hemoglobin, Kalium has at least one tie between the positive actual state group and the negative actual state group. Statistics may be biased.

a. Under the nonparametric assumption

b. Null hypothesis: true area $=0.5$ 
medRxiv preprint doi: https://doi.org/10.1101/2021.01.15.21249916; this version posted January 20, 2021. The copyright holder for this preprint (which was not certified by peer review) is the author/funder, who has granted medRxiv a license to display the preprint in perpetuity.

All rights reserved. No reuse allowed without permission.

Table 12. Area under the curve (AUC) of clinical prediction model for age, BUN, serum creatinine, eGFR, systolic blood pressure, diastolic blood pressure, hemoglobin level and serum potassium. Prediction of frontal axis deviation by age, BUN, serum creatinine, eGFR, systolic blood pressure, diastolic blood pressure, hemoglobin level and serum potassium. $P<0.001$ for all ROC curves compared with 0.5 curves.

\begin{tabular}{lr|r|r|r|r} 
& & & \multicolumn{2}{c}{ Area Under the Curve } & \multicolumn{2}{c}{$\begin{array}{c}\text { Asymptotic 95\% Confidence } \\
\text { Interval }\end{array}$} \\
\hline Test Result Variable(s) & Area & Std. Error & $\begin{array}{r}\text { Asymptotic } \\
\text { Sig. }\end{array}$ & \multicolumn{2}{c}{$\begin{array}{c}\text { Lower Bound } \\
\text { Upper Bound }\end{array}$} \\
\hline Age &, 442 &, 067 &, 383 &, 311 &, 573 \\
\hline BUN &, 526 &, 071 &, 697 &, 388 &, 664 \\
\hline Creatinin &, 462 &, 065 &, 567 &, 335 &, 589 \\
\hline eGFR &, 524 &, 067 &, 722 &, 393 &, 654 \\
\hline Systole &, 443 &, 069 &, 391 &, 308 &, 578 \\
\hline Diastole &, 477 &, 070 &, 729 &, 339 &, 615 \\
\hline Hemoglobin &, 693 &, 067 &, 004 &, 561 &, 825 \\
\hline Kalium &, 467 &, 062 &, 627 &, 346 &, 589 \\
\hline
\end{tabular}

The test result variable(s): Age, BUN, Systole, Diastole, Hemoglobin, Kalium has at least one tie between the positive actual state group and the negative actual state group. Statistics may be biased.

a. Under the nonparametric assumption

b. Null hypothesis: true area $=0.5$ 
medRxiv preprint doi: https://doi.org/10.1101/2021.01.15.21249916; this version posted January 20, 2021. The copyright holder for this preprint (which was not certified by peer review) is the author/funder, who has granted medRxiv a license to display the preprint in perpetuity.

All rights reserved. No reuse allowed without permission.

\begin{tabular}{|c|c|c|c|c|c|c|}
\hline \multirow{2}{*}{ Variable } & \multicolumn{3}{|c|}{ Univariate Analysis } & \multicolumn{3}{|c|}{ Multivariate Analysis } \\
\hline & HR & $95 \%$ CI & $P$ value & HR & $95 \%$ CI & $P$ value \\
\hline Age & 0.993 & $0.970-1.017$ & 0.568 & & & \\
\hline Man gender & 0.991 & $0.566-1.736$ & 0.975 & & & \\
\hline BUN & 0.983 & $0.959-1.007$ & 0.164 & & & \\
\hline Creatinine & 1.009 & $0.974-1.045$ & 0.621 & & & \\
\hline eGFR & 0.997 & $0.978-1.017$ & 0.793 & & & \\
\hline Systolic blood pressure & 1.011 & $1.001-1.022$ & 0.038 & 1.018 & $1.000-1.021$ & 0.042 \\
\hline Diastolic blood pressure & 1.011 & $0.994-1.029$ & 0.215 & & & \\
\hline Kalium & 0.829 & $0.634-1.084$ & 0.170 & & & \\
\hline
\end{tabular}

Table 13. Univariate and multivariate logistic regression for prediction of ECG abnormalities among chronic kidney disease patients 
medRxiv preprint doi: https://doi.org/10.1101/2021.01.15.21249916; this version posted January 20, 2021. The copyright holder for this preprint (which was not certified by peer review) is the author/funder, who has granted medRxiv a license to display the preprint in perpetuity.

\section{FIGURE LEGENDS}

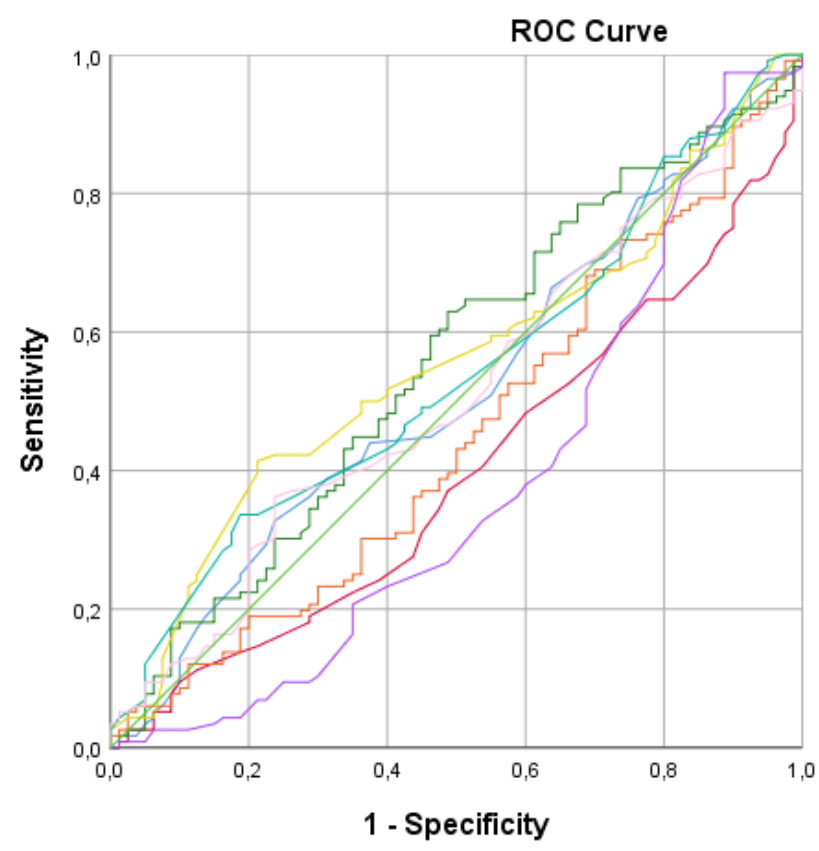

$$
\begin{gathered}
\begin{array}{c}
\text { Source of the } \\
\text { Curve }
\end{array} \\
\text { Age } \\
\text { - BUN } \\
- \text { Creatinin } \\
\text { eGFR } \\
\text { Systole } \\
\text { Diastole } \\
\text { Hemoglobin } \\
\text { Kalium } \\
\text { Reference Line }
\end{gathered}
$$

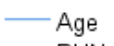

Diagonal segments are produced by ties.

Figure 1. Receiver operator characteristic analysis of the clinical prediction model for age, BUN, serum creatinine, eGFR, systolic blood pressure, diastolic blood pressure, hemoglobin level and serum potassium. Prediction of long QT interval by age, BUN, serum creatinine, eGFR, systolic blood pressure, diastolic blood pressure, hemoglobin level and serum potassium. $P<0.001$ for all ROC curves compared with 0.5 curves. 
medRxiv preprint doi: https://doi.org/10.1101/2021.01.15.21249916; this version posted January 20, 2021. The copyright holder for this preprint (which was not certified by peer review) is the author/funder, who has granted medRxiv a license to display the preprint in perpetuity. All rights reserved. No reuse allowed without permission.
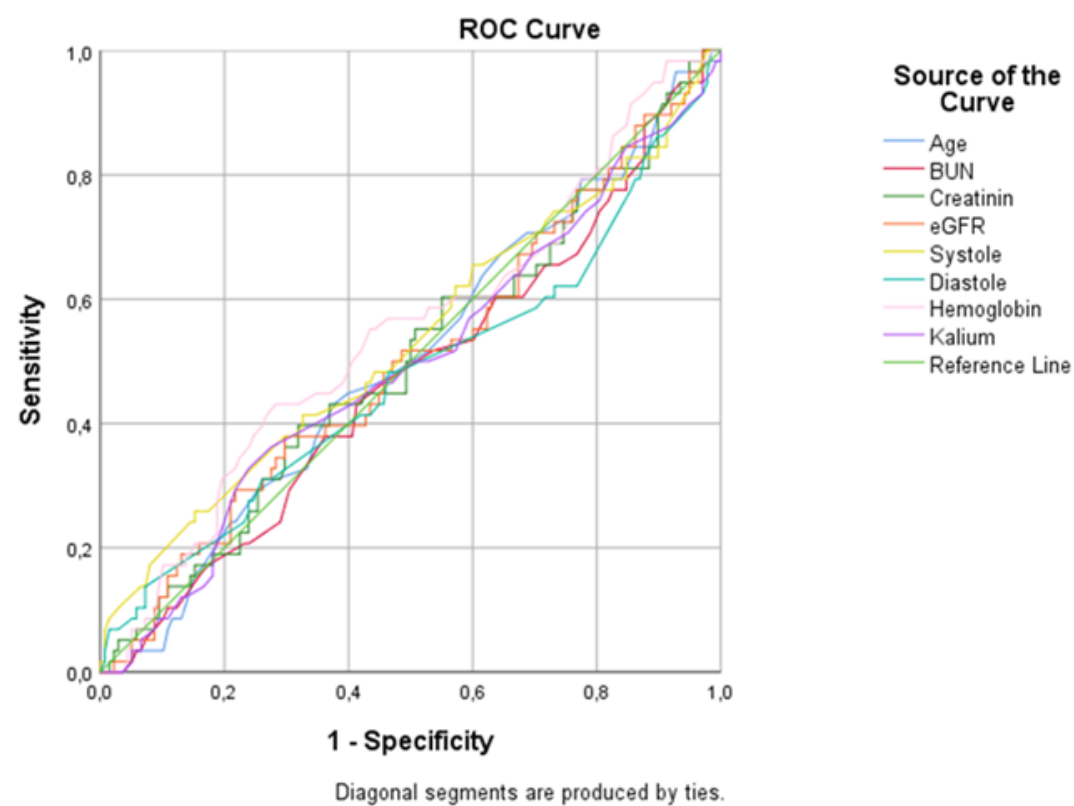

Figure 2. Receiver operator characteristic analysis of the clinical prediction model for age, BUN, serum creatinine, eGFR, systolic blood pressure, diastolic blood pressure, hemoglobin level and serum potassium. Prediction of fragmented QRS by age, BUN, serum creatinine, eGFR, systolic blood pressure, diastolic blood pressure, hemoglobin level and serum potassium. $P<0.001$ for all ROC curves compared with 0.5 curves. 
medRxiv preprint doi: https://doi.org/10.1101/2021.01.15.21249916; this version posted January 20, 2021. The copyright holder for this preprint (which was not certified by peer review) is the author/funder, who has granted medRxiv a license to display the preprint in perpetuity. All rights reserved. No reuse allowed without permission.
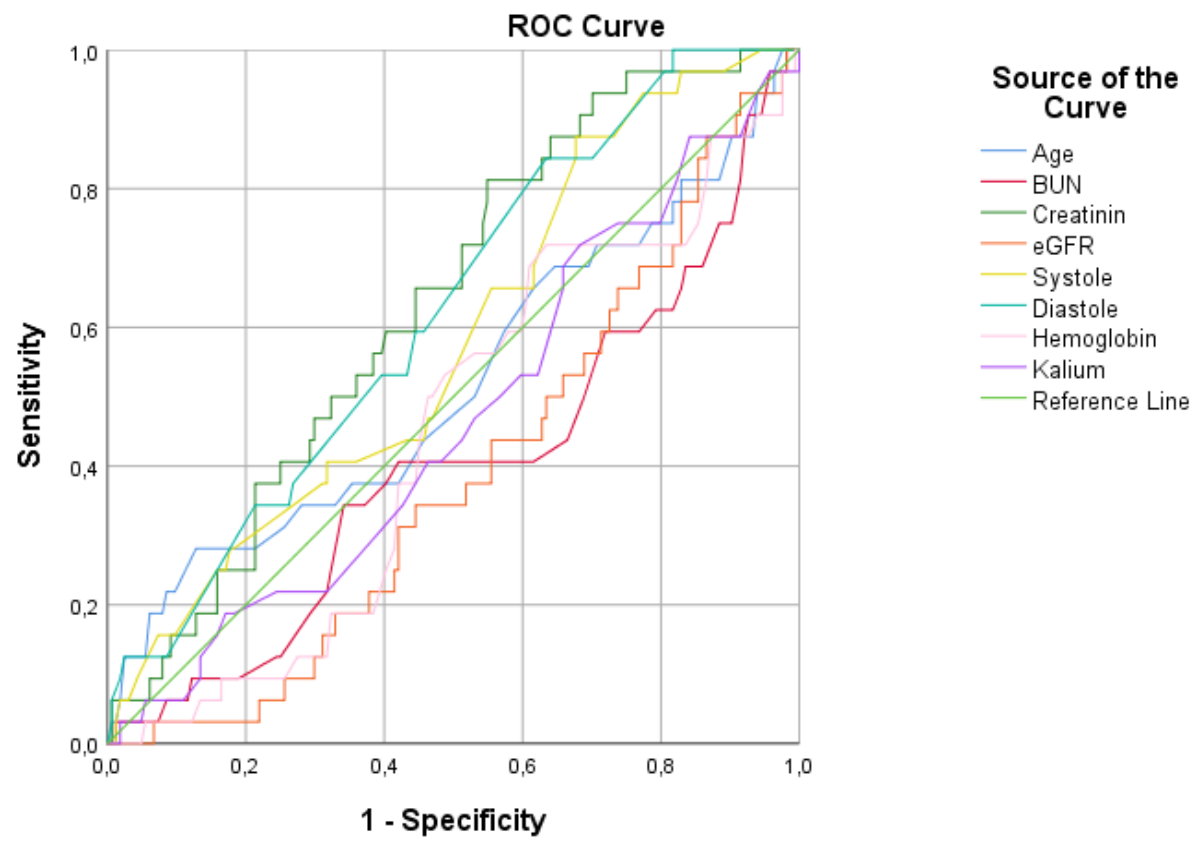

Diagonal segments are produced by ties.

Figure 3. Receiver operator characteristic analysis of the clinical prediction model for age, BUN, serum creatinine, eGFR, systolic blood pressure, diastolic blood pressure, hemoglobin level and serum potassium. Prediction of LVH by age, BUN, serum creatinine, eGFR, systolic blood pressure, diastolic blood pressure, hemoglobin level and serum potassium. $P<0.001$ for all ROC curves compared with 0.5 curves. 
medRxiv preprint doi: https://doi.org/10.1101/2021.01.15.21249916; this version posted January 20, 2021. The copyright holder for this preprint (which was not certified by peer review) is the author/funder, who has granted medRxiv a license to display the preprint in perpetuity. All rights reserved. No reuse allowed without permission.

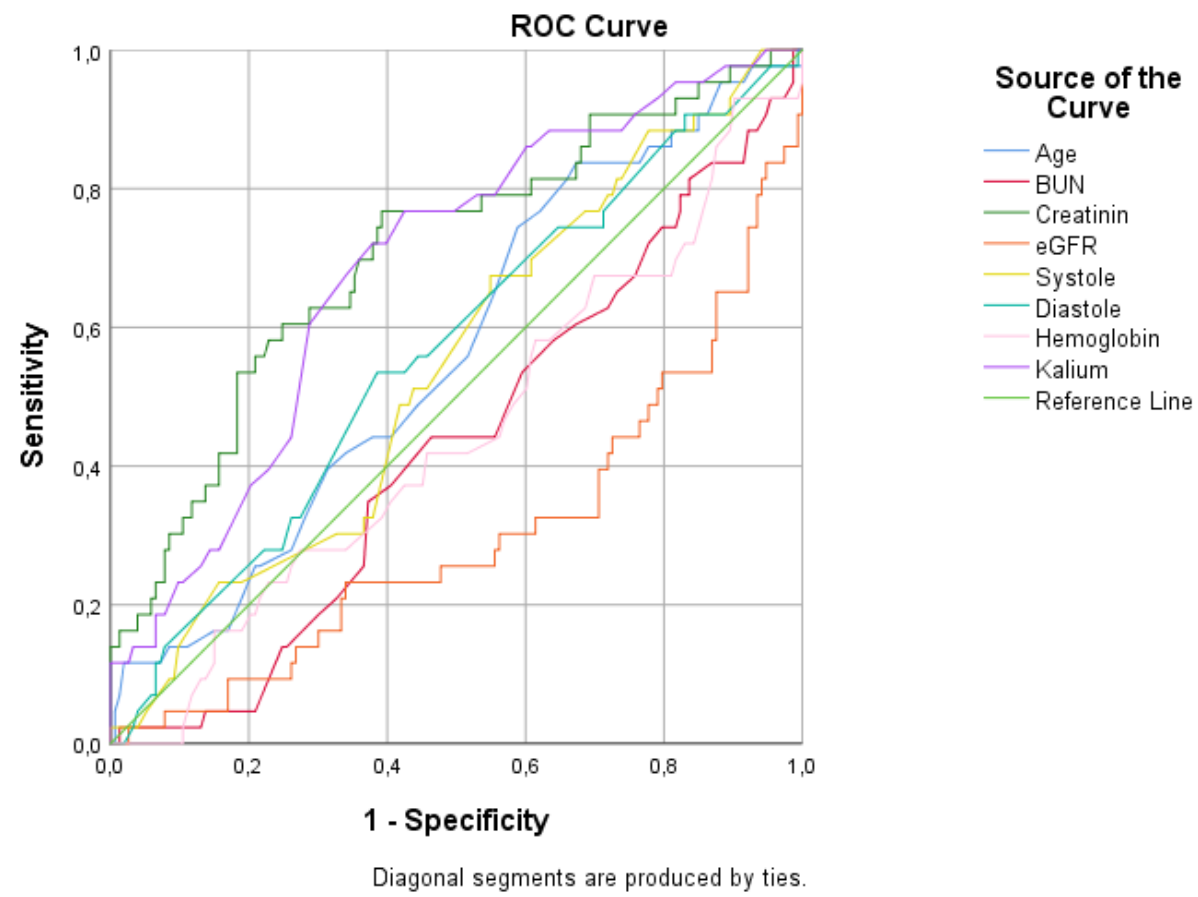

Figure 4. Receiver operator characteristic analysis of the clinical prediction model for age, BUN, serum creatinine, eGFR, systolic blood pressure, diastolic blood pressure, hemoglobin level and serum potassium. Prediction of peaked T wave by age, BUN, serum creatinine, eGFR, systolic blood pressure, diastolic blood pressure, hemoglobin level and serum potassium. $P<0.001$ for all ROC curves compared with 0.5 curves. 
medRxiv preprint doi: https://doi.org/10.1101/2021.01.15.21249916; this version posted January 20, 2021. The copyright holder for this preprint (which was not certified by peer review) is the author/funder, who has granted medRxiv a license to display the preprint in perpetuity. All rights reserved. No reuse allowed without permission.

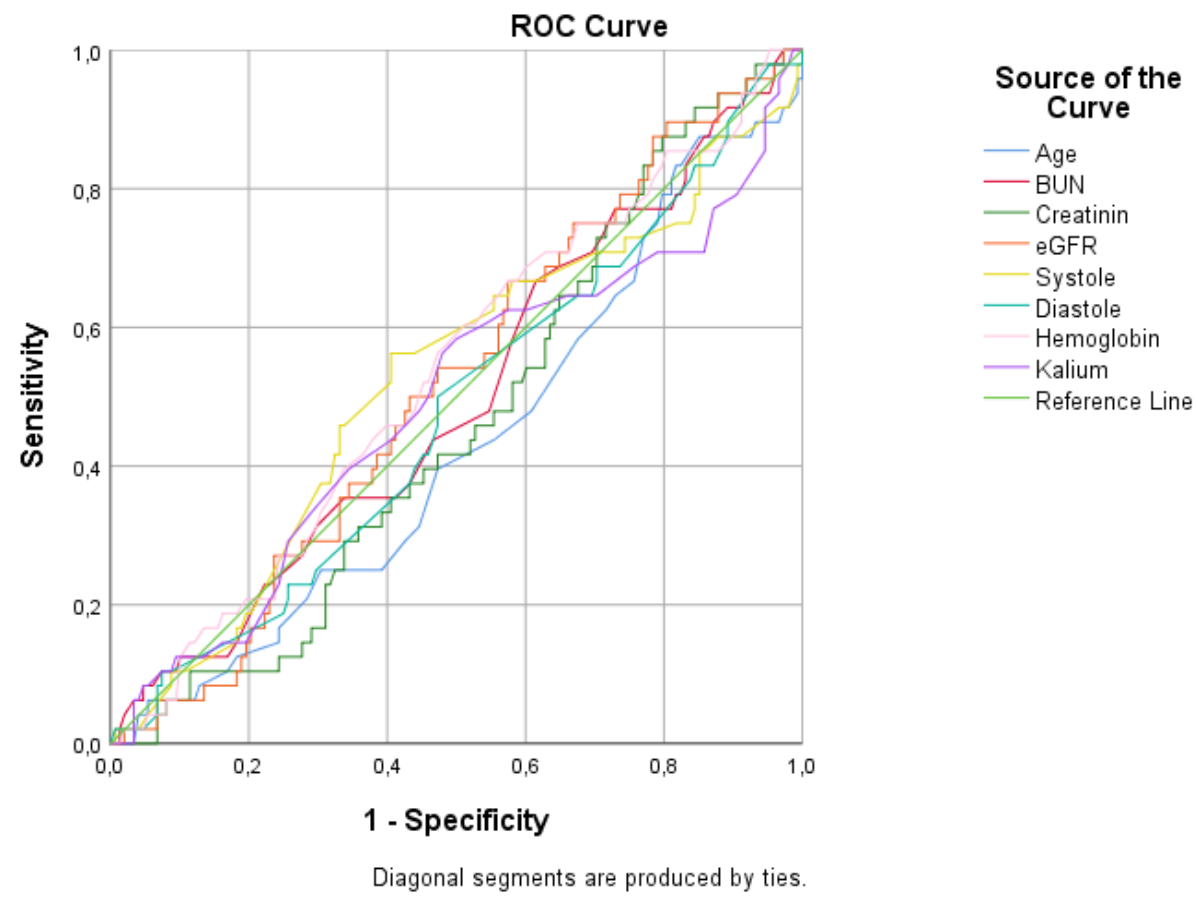

Figure 5. Receiver operator characteristic analysis of the clinical prediction model for age, BUN, serum creatinine, eGFR, systolic blood pressure, diastolic blood pressure, hemoglobin level and serum potassium. Prediction of poor precordial R wave progression by age, BUN, serum creatinine, eGFR, systolic blood pressure, diastolic blood pressure, hemoglobin level and serum potassium. $P<0.001$ for all ROC curves compared with 0.5 curves. 
medRxiv preprint doi: https://doi.org/10.1101/2021.01.15.21249916; this version posted January 20, 2021. The copyright holder for this preprint (which was not certified by peer review) is the author/funder, who has granted medRxiv a license to display the preprint in perpetuity. All rights reserved. No reuse allowed without permission.
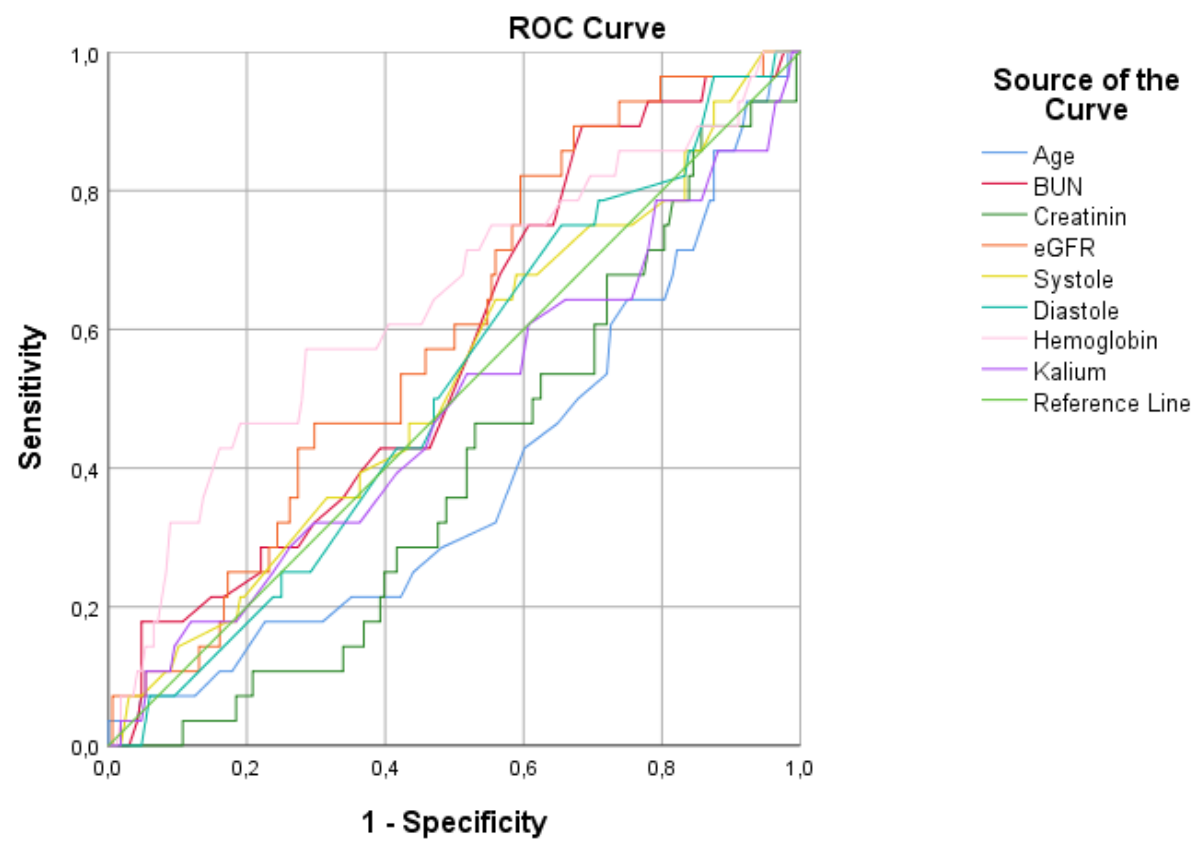

Diagonal segments are produced by ties.

Figure 6. Receiver operator characteristic analysis of the clinical prediction model for age, BUN, serum creatinine, eGFR, systolic blood pressure, diastolic blood pressure, hemoglobin level and serum potassium. Prediction of pathological $Q$ wave by age, BUN, serum creatinine, eGFR, systolic blood pressure, diastolic blood pressure, hemoglobin level and serum potassium. $P<0.001$ for all ROC curves compared with 0.5 curves. 
medRxiv preprint doi: https://doi.org/10.1101/2021.01.15.21249916; this version posted January 20, 2021. The copyright holder for this preprint (which was not certified by peer review) is the author/funder, who has granted medRxiv a license to display the preprint in perpetuity. All rights reserved. No reuse allowed without permission.
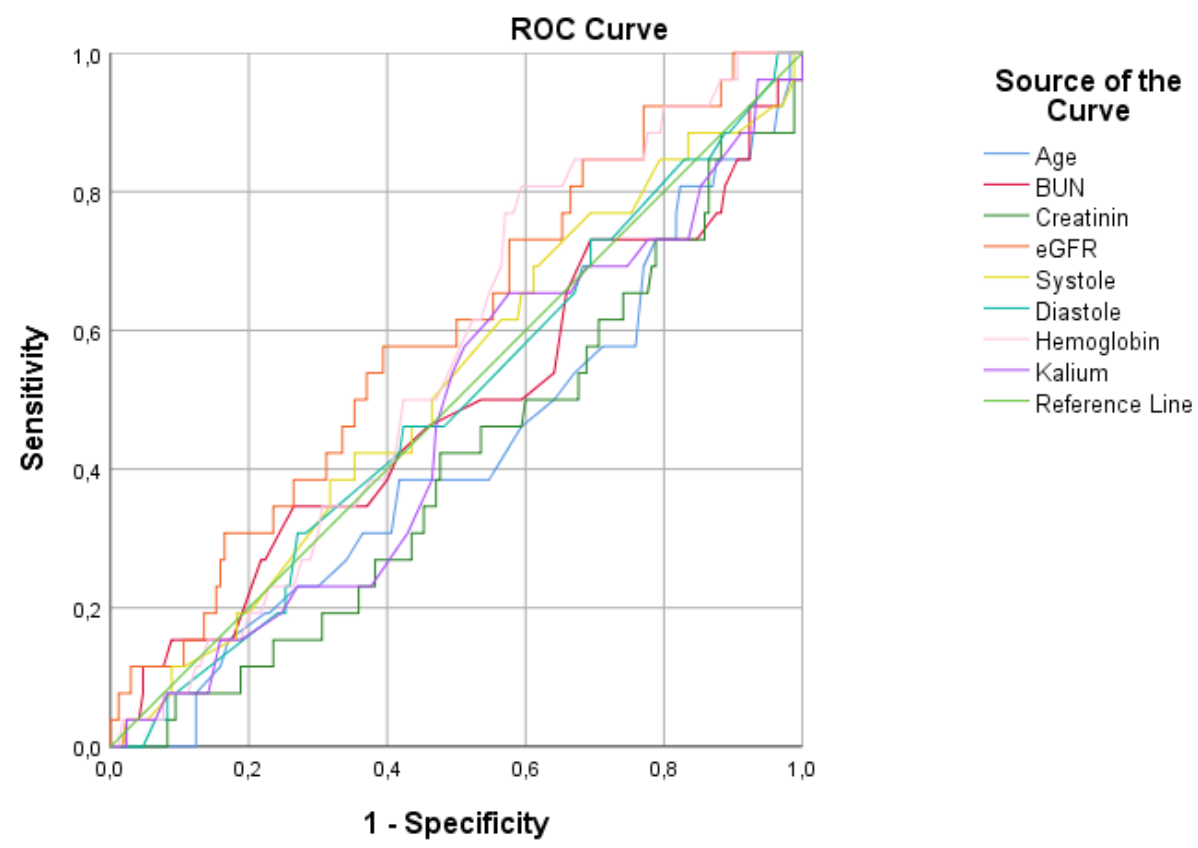

Diagonal segments are produced by ties.

Figure 7. Receiver operator characteristic analysis of the clinical prediction model for age, BUN, serum creatinine, eGFR, systolic blood pressure, diastolic blood pressure, hemoglobin level and serum potassium. Prediction of non-specific ST-T changes by age, BUN, serum creatinine, eGFR, systolic blood pressure, diastolic blood pressure, hemoglobin level and serum potassium. $P<0.001$ for all ROC curves compared with 0.5 curves. 
medRxiv preprint doi: https://doi.org/10.1101/2021.01.15.21249916; this version posted January 20, 2021. The copyright holder for this preprint (which was not certified by peer review) is the author/funder, who has granted medRxiv a license to display the preprint in perpetuity. All rights reserved. No reuse allowed without permission.
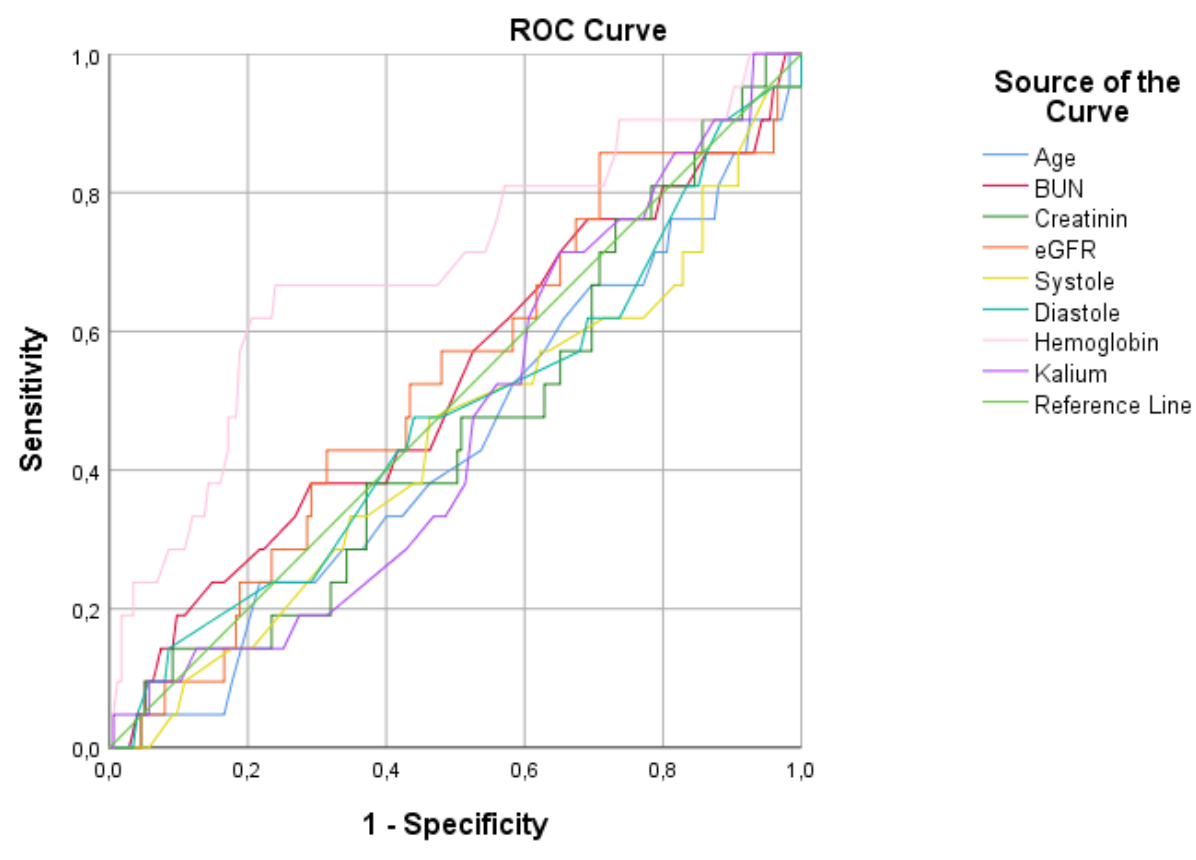

Diagonal segments are produced by ties.

Figure 8. Receiver operator characteristic analysis of the clinical prediction model for age, BUN, serum creatinine, eGFR, systolic blood pressure, diastolic blood pressure, hemoglobin level and serum potassium. Prediction of frontal axis deviation by age, BUN, serum creatinine, eGFR, systolic blood pressure, diastolic blood pressure, hemoglobin level and serum potassium. $P<0.001$ for all ROC curves compared with 0.5 curves. 